Donald, H. B. \& IsaAcs, A. (1954). J. gen. Microbiol. 11, 325-331.

\title{
Some Properties of Influenza Virus Filaments shown by Electron Microscopic Particle Counts
}

\author{
By HEATHER B. DONALD and A. ISAACS \\ National Institute for Medical Research, London, N.W. 7
}

\begin{abstract}
SUMMARY: A strain of influenza virus A which produced abundant filaments was more efficient in agglutinating red cells than non-filamentous strains. This was shown by counts of the number of particles (i.e. filaments and spheres)/agglutinating dose; the ratios found were $10^{6 \cdot 6}$ for the filamentous, and $10^{7 \cdot 2}$ for the non-filamentous strains. The increased efficiency of agglutination was shown by filtration experiments to be due to the filaments. There was no corresponding increase in the efficiency of initiating infection. Treatment of a filamentous preparation with ultrasonic vibrations caused breakdown of the filaments, an increase in agglutination titre but no change in the infectivity titre.
\end{abstract}

In a recent study of counts of influenza virus particles by electron microscopy it was found that for four strains of virus examined there was an average of $10^{7.2}$ virus particles/agglutinating dose, as defined below (Donald \& Isaacs, 1954). One strain gave a figure of $10^{6.9}$ in two different experiments, however, and it was noticed that these two preparations contained a number of filamentous forms of virus. The possibility was considered, therefore, that virus filaments might show different agglutinating or infective behaviour from spherical forms. This possibility was investigated with a strain of influenza virus, A/Persian Gulf/2/52, known to produce many filamentous forms. This paper reports the results of our investigation.

\section{MATERIALS AND METHODS}

The techniques for counting and biological assay of influenza virus described in an earlier paper (Donald \& Isaacs, 1954) were used with only a few modifications.

Technique of counting. Previously two techniques were employed-a spray technique and counts of the number of particles adsorbed on fowl red cell ghosts; these two techniques gave essentially the same results. The spray technique was unsuitable for the present experiments, however, since virus filaments were not found in sprayed materials. The red cell technique was therefore used alone. For purposes of counting each filament was counted as a single particle.

Agglutinating dose. An agglutinating dose (A.D.) is defined as the least amount of virus which causes partial $(50 \%)$ agglutination of $0.25 \mathrm{ml}$. of a $1 \%$ suspension of chick red cells (approximately $10^{7 \cdot 15}$ cells) in a pattern test.

Infectivity titrations. Titrations were carried out in the allantoic cavity of the chick embryo as described previously and with 4 eggs/half-log dilution.

Ultrasonic treatment. For the $350 \mathrm{kc}$. treatment a quartz crystal oscillator 
built at the National Institute for Medical Research was used. Experiments were carried out at a power output of $15 \mathrm{~W} . / \mathrm{cm} .^{2}$ with an effective crystal area of $19 \mathrm{~cm} .{ }^{2}$. Volumes $(3.0 \mathrm{ml}$.) of the allantoic fluids to be treated were contained in soda glass test tubes $19 \mathrm{~cm}$. long and of $1 \mathrm{~cm}$. internal diameter. Runs of 3 min. were carried out in $\frac{1}{2} \mathrm{~min}$. bursts, with immersion of the tubes at $0^{\circ}$ between bursts, so that the temperature of the fluids under test at no time exceeded $30^{\circ}$.

A magnetostriction generator was used for the $6 \mathrm{kc}$. tests. Because of the low power output of this machine, fluids were contained in tubes with polythene bases.

\section{RESULTS}

The strain of virus used in these experiments produces large numbers of filamentous forms during its growth in the allantoic cavity of the chick embryo. The appearance on electron microscopy is illustrated in Pl. 1, fig. 1. Counts were made of the number of filaments + spheres in different preparations; the counts were related in each case to the agglutination titre of the corresponding preparation. The results of a number of experiments are shown in Table 1; they are expressed as the ratio of particles counted (i.e. particles $=$ filaments + spheres)/agglutinating dose. For comparison, the results of counts of nonfilamentous strains are shown.

Table 1. Comparison of ratio of particles to an agglutinating dose in filamentous and non-filamentous strains of influenza virus

Virus

Ratio $\left(\log _{10}\right)$ of particles to an agglutinating dose

Filamentous strain (A/ $6 \cdot 4,6 \cdot 7,6 \cdot 5,6 \cdot 6,6 \cdot 6,6 \cdot 6,6 \cdot 6,6 \cdot 7,6 \cdot 5,6 \cdot 6,6 \cdot 6,6 \cdot 5,6 \cdot 5,6 \cdot 6,6 \cdot 6,6 \cdot 6$ Persian Gulf/2/52)

Non-filamentous strains $7 \cdot 3,7 \cdot 4,7 \cdot 2,7 \cdot 1,7 \cdot 3,7 \cdot 1,7 \cdot 3,7 \cdot 1,6 \cdot 9,7 \cdot 3,7 \cdot 3,7 \cdot 2,7 \cdot 3,7 \cdot 2,7 \cdot 2$

Mean ratio for filamentous strain $6 \cdot 6 \pm 0 \cdot 08$

Mean ratio for non-filamentous strains $7 \cdot 2 \pm 0 \cdot 13$ Difference 0.6 $\pm 0 \cdot 15$

$t=15.9 ; \quad m=29 ; \quad p<0 \cdot 001$

It is clear that $\mathbf{A} /$ Persian Gulf/2/52 gives a significantly lower ratio of particles/agglutinating dose than strains without filaments. These results show that agglutination is a more efficient process, i.e. fewer particles are required to cause a standard amount of agglutination in A/Persian Gulf/2/52 than in the other strains. By themselves, the results do not, however, allow us to conclude whether it is the filaments which are responsible for the increased efficiency of agglutination, rather than a strain peculiarity of another sort. To answer this question two types of experiment were undertaken; filtration was successful but centrifugation unsuccessful in separating filaments from elementary bodies.

\section{Filtration experiments}

Allantoic fluid from eggs infected with $\mathrm{A} / \mathrm{Persian}$ Gulf/2/52 virus was filtered through collodion membranes of average pore diameter (A.P.D.) about $0.7 \mu$. Filtration usually resulted in a loss of about $75-90 \%$ of the virus 
haemagglutinin and filtrates contained no long filamentous forms but only spheres and short rods (Pl. 1, fig. 2). Counts were made of number of particles/ agglutinating dose in filtrates and the results compared with the same materials before filtration. The results are shown in Table 2 . It is clear that the ratio for filtrates is significantly higher than the ratio for the unfiltered fluids. We conclude therefore that the increased efficiency of agglutination shown by this strain of virus is due to its filamentous forms.

Table 2. Effect of filtration through a collodion membrane (A.P.D. $0.7 \mu)$ on the ratio of particles to an agglutinating dose in A/Persian Gulf/2/52 virus

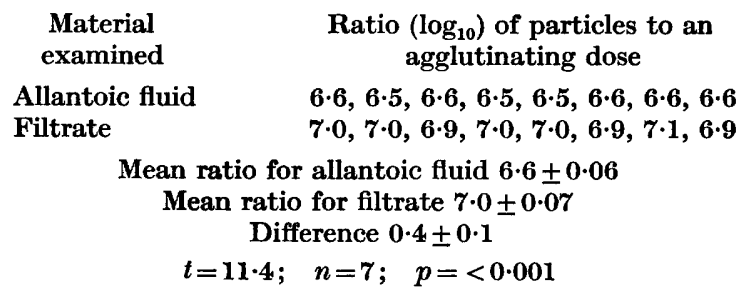

\section{Centrifugation experiments}

The filaments were readily sedimented by low-speed centrifugation, $1500 \mathrm{~g}$ for $15 \mathrm{~min}$. The deposits after centrifugation always contained many spherical forms in addition to filaments; however, we do not know whether these spheres are carried down on larger particles or result from breaking of the filaments during centrifugation and re-suspension of the deposit. Nevertheless deposits usually contained a slightly higher proportion of filaments to spheres than the original fluids; in one experiment the proportion of filaments rose from 33-75\%. Electron micrographs of the supernatant and deposit obtained after centrifugation for $15 \mathrm{~min}$. at $1500 \mathrm{~g}$ are shown in Pl. 2, figs. 3 and 4 . Counts of the ratio of particles/agglutinating dose in the supernatants and deposits are shown in Table 3. The supernatants gave slightly higher ratios but the difference between the two is not statistically significant.

Table 3. Effect of centrifugation at $1500 \mathrm{~g}$ on the ratio of particles to an agglutinating dose in A/Persian Gulf/2/52

Material

$\begin{array}{cccccc}\text { Supernatant after centrifugation } & 7 \cdot 1 & 7 \cdot 0 & 6 \cdot 7 & 6 \cdot 6 & 6 \cdot 7 \\ \text { Deposit after centrifugation } & 6 \cdot 8 & 6 \cdot 6 & 6 \cdot 6 & 6 \cdot 5 & 6 \cdot 7 \\ \text { Mean ratio for supernatant } 6 \cdot 8 \pm 0 \cdot 2 & \\ \text { Mean ratio for deposit } 6 \cdot 6 \pm 0 \cdot 1 & \\ \text { Difference } 0 \cdot 2 \pm 0 \cdot 25 & \\ t=2 \cdot 4 ; \quad n=4 ; 0 \cdot 1>p>0 \cdot 05\end{array}$

Effect of ultrasonics on influenza virus filaments

It was of interest to see what effect breaking influenza virus filaments would have on the agglutination titre and on the ratio of particles to an agglutinating dose. Accordingly treatment with ultrasonics was carried out using 3-min. treatments at $6 \mathrm{kc}$. and $350 \mathrm{kc}$. 
Treatment at $6 \mathrm{kc}$. produced a rise in the agglutination titre of A/Persian Gulf/2/52 virus of 2- to 4-fold. The deposit after centrifugation at $1500 \mathrm{~g}$ for 15 min. showed a similar rise in titre after ultrasonic treatment but filtrates through $0.7 \mu$. A.P.D. membranes showed no rise in titre. Treatment at $350 \mathrm{kc}$. produced a 2- to 6.5-fold rise in agglutinin titre with $\mathrm{A} / \mathrm{Persian}$ Gulf/2/52 virus. Non-filamentous strains, e.g. P.R. 8 or N.W.S. or a filtrate of A/Persian Gulf/ 2/52 tested at the same time, showed no significant changes in agglutinin titre. Results of some representative experiments illustrating these points are shown in Table 4. The appearances found after treatment with ultrasonics are

\section{Table 4. Effect of ultrasonic vibrations on the haemagglutinin titre} of filamentous and non-filamentous strains of influenza virus

\begin{tabular}{|c|c|c|c|c|}
\hline \multirow[b]{2}{*}{ Expt. } & \multirow[b]{2}{*}{$\begin{array}{l}\text { Virus material } \\
\text { tested }\end{array}$} & \multirow{2}{*}{$\begin{array}{l}\text { Frequency } \\
\text { of ultrasonic } \\
\text { vibration } \\
\text { used } \\
\text { (k.c.) }\end{array}$} & \multicolumn{2}{|c|}{ Haemagglutinin titre } \\
\hline & & & $\begin{array}{c}\text { Before } \\
\text { treatment }\end{array}$ & $\underset{\text { After }}{\text { treatment }}$ \\
\hline 1 & $\begin{array}{l}\text { A/Persian Gulf } / 2 / 52 \\
\text { A/Persian Gulf } / 2 / 52 \text { filtrate }\end{array}$ & $\begin{array}{l}350 \\
350\end{array}$ & $\begin{array}{l}960 \\
240\end{array}$ & $\begin{array}{r}6400 \\
360\end{array}$ \\
\hline 2 & $\begin{array}{l}\text { A/Persian Gulf } / 2 / 52 \\
\text { N.W.S. (non-filamentous) }\end{array}$ & $\begin{array}{l}\mathbf{3 5 0} \\
\mathbf{3 5 0}\end{array}$ & $\begin{array}{l}\mathbf{3 8 4 0} \\
\mathbf{2 5 6 0}\end{array}$ & $\begin{array}{r}17,920 \\
3200\end{array}$ \\
\hline 3 & $\begin{array}{l}\text { A/Persian Gulf/2/52 deposit } \\
\text { A/Persian Gulf/2/52 filtrate }\end{array}$ & $\begin{array}{l}6 \\
6\end{array}$ & $\begin{array}{r}80 \\
100\end{array}$ & $\begin{array}{r}320 \\
80\end{array}$ \\
\hline 4 & $\begin{array}{l}\text { A/Persian Gulf/2/52 } \\
\text { A/Persian Gulf } / 2 / 52 \text { deposit } \\
\text { A/Persian Gulf } / 2 / 52 \text { filtrate }\end{array}$ & $\begin{array}{l}6 \\
6 \\
6\end{array}$ & $\begin{array}{r}960 \\
60 \\
240\end{array}$ & $\begin{array}{r}1920 \\
120 \\
240\end{array}$ \\
\hline
\end{tabular}

Filtrate: obtained after filtration through $0 \cdot 7 \mu$. A.P.D. membrane. Deposit: obtained after centrifugation for 15 minutes at $1500 \mathrm{~g}$.

shown in Pl. 2, figs. 5 and 6. It will be seen that most of the larger filaments had broken up into rods and spheres. No significant changes in the ratio of particles to an agglutinating dose were found after treatment at $6 \mathrm{kc}$. At $350 \mathrm{kc}$. it appeared that quite a considerable rise in ratio occurred, but as can be seen from inspection of Pl. 2, fig. 6, it is often extremely difficult to decide which particles to count owing to the debris present. This question was therefore not investigated further.

\section{The relative infectivity of virus filaments and spherical forms}

It was found on examining strains containing mainly spheres that the average ratio of particles to an agglutinating dose was $10^{7 \cdot 2}$, the average ratio of infective doses (I.D. 50) to an agglutinating dose was $10^{6.1}$ and hence that roughly 10 virus particles corresponded to one I.D. 50 dose. Since filaments were more efficient agglutinating agents than spheres it was of interest to see whether they were also more efficient infective agents. It was surprising to find, however, that A/Persian Gulf/2/52 gave a significantly lower ratio of I.D. 50 to an agglutinating dose than did other strains we have examined, and that the ratio of particles to an I.D. 50 with this strain was again about 10.

In order to measure the contribution of the virus filaments to the infectivity 
of a preparation of virus it was necessary to be able to separate filaments from spheres efficiently. By filtration it has been possible to obtain spheres free of filaments but we have not been able to obtain a preparation of filaments free of spheres. The infectivity titres of preparations of freshly harvested allantoic fluid, filtrate and deposit after light centrifugation were measured and at the same time the agglutination titres, fraction of filaments to total particles expressed as a percentage, and total particle counts were noted. From these findings it was possible to calculate the ratio I.D. 50 doses/agglutinating dose, particles/agglutinating dose, and particles/I.D. 50 dose for preparations containing different proportions of filaments to elementary bodies. The results are shown in Table 5. The variations found in the ratios of particles/I.D. 50 dose for allantoic fluid, filtrate or deposit after centrifugation in different experiments, showed no consistent trends. The present techniques do not therefore show any differences in the relative infectivity of virus filaments and spheres.

Table 5. Effect of filtration and centrifugation on infectivity of $A / P e r s i a n$ Gulf/2/52 virus

\begin{tabular}{|c|c|c|c|c|c|c|c|c|}
\hline \multirow[b]{3}{*}{ Experiment: } & \multicolumn{8}{|c|}{ Material } \\
\hline & & $\begin{array}{l}\text { lantoic } \\
\text { fluid }\end{array}$ & & Filt & trate & & & eposit \\
\hline & 12 & $\begin{array}{lll}3 & 4 & 5\end{array}$ & 5 & 12 & $\begin{array}{ll}3 & 4\end{array}$ & 51 & 2 & $\begin{array}{ll}3 & 4 \\
\end{array}$ \\
\hline $\begin{array}{l}\text { Ratio }\left(\log _{10}\right) \text { I.D. 50/A.D.: } \\
\text { Ratio }\left(\log _{10}\right) \text { particles/A.D.: } \\
\text { Ratio }\left(\log _{10}\right) \text { particles/I.D. 50: } \\
\text { Filaments }(\%) \text { : }\end{array}$ & $\begin{array}{l}4 \cdot 95 \cdot 8 \\
6 \cdot 66 \cdot 5 \\
1 \cdot 70 \cdot 7 \\
4060\end{array}$ & $\begin{array}{l}5 \cdot 65 \cdot 45 \\
6 \cdot 66 \cdot 66 \\
1 \cdot 01 \cdot 21 . \\
40503\end{array}$ & & 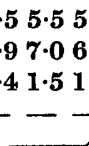 & $\begin{array}{l}5.95 .55 \\
6.97 \cdot 16 \\
1.01 .61 \\
-1 .-1\end{array}$ & $\begin{array}{rl}5 \cdot 6 & 4 \cdot 8 \\
6 \cdot 9 & 6 \cdot 6 \\
1 \cdot 3 & 1 \cdot 8 \\
- & 50\end{array}$ & $\begin{array}{l}85 \cdot 65 \\
66.56 \\
80.90 \\
070\end{array}$ & $\begin{array}{l}5.95 \cdot 35 \\
6 \cdot 66.56 \\
0.71 \cdot 21 \\
60 \quad 647\end{array}$ \\
\hline $\begin{array}{l}\text { Mean ratio }\left(\log _{10}\right) \text { I.D. 50/A.D.: } \\
\text { Mean ratio }\left(\log _{10}\right) \text { particles/A.D.: } \\
\text { Mean ratio }\left(\log _{10}\right) \text { particles/I.D. 50: } \\
\text { Mean percentage filaments: }\end{array}$ & & $\begin{array}{l}5 \cdot 4 \\
6 \cdot 6 \\
1 \cdot 2 \\
45\end{array}$ & & & $\begin{array}{l}5 \cdot 6 \\
7 \cdot 0 \\
1 \cdot 4 \\
-\end{array}$ & & & $\begin{array}{l}5 \cdot 4 \\
6 \cdot 5 \\
1 \cdot 1 \\
64\end{array}$ \\
\hline
\end{tabular}

\section{Effect of ultrasonics on the infectivity of filamentous preparations of influenza virus}

A number of experiments was carried out to test the effect of ultrasonic treatment at $6 \mathrm{kc}$. and $350 \mathrm{kc}$. on the infectivity of A/Persian Gulf/2/52 virus. Invariably there was no significant change in infectivity titre following treatment with ultrasonic vibrations. Thus in one experiment the haemagglutinin titre rose after treatment at $350 \mathrm{kc}$. from 1600 to 10,240 but the infectivity titre (titrated twice) remained unchanged. Ultrasonic treatment of a nonfilamentous strain under similar conditions $(350 \mathrm{kc}$.) produced no change in infectivity.

\section{DISCUSSION}

These experiments show that the ratio of particles to an agglutinating dose is about $0 \cdot 6 \mathrm{log}$ unit higher for a filamentous than for a non-filamentous strain of influenza virus. If we take into account the fact that the filamentous strains contained on the average about $\mathbf{5 0} \%$ filaments and $\mathbf{5 0} \%$ spherical forms we 
can conclude that a virus filament is, on the average, about 7 or 8 times more efficient than a sphere in producing agglutination in the pattern test. It is interesting to note therefore that it was possible to increase the agglutinin titre of a filamentous preparation up to 6.5 times by treatment with ultrasonic vibrations at $350 \mathrm{kc}$. Thus on ultrasonic treatment $20-40$ agglutinating units, on the average, appear to have been produced for each filament; this figure is necessary to account for the decrease in the efficiency of agglutination and the rise in agglutinin titre which occurred.

Filamentous forms of influenza virus were first noted by Mosley \& Wyckoff (1946). Chu, Dawson \& Elford (1949) found that recently-isolated strains of influenza virus A frequently showed long filamentous forms and they demonstrated that the filaments possessed many of the properties of influenza virus elementary bodies. Hoyle (1950) made dark field microscopic observations which led him to conclude that protrusions of the allantoic cells occur in normal and in infected membranes and that the protrusions in the infected membranes contain virus material. Wyckoff (1951) examined by electron microscopy ultra-thin sections through cells which were apparently excreting influenza virus filaments; he found that the contents of the filaments were continuous with those of the cell cytoplasm. The work of Chu, Dawson \& Elford (1949), Hoyle (1950), Murphy, Karzon \& Bang (1950) and Wyckoff (1951) suggests that, during the growth of most strains of influenza virus $A$, filaments are formed first and later break down to give spherical forms, but that in many recently isolated strains, such as $\mathrm{A} /$ Persian Gulf/2/52, this last process is slowed down. The results of our experiments with ultrasonic treatment of a filamentous virus strain suggest that natural breakdown of filaments to spheres would cause a rise in haemagglutinin titre. A rise in haemagglutinin titre as a result of natural breakdown of filaments might be accompanied either by no change in infectivity titre or by a corresponding rise in infectivity. A rise in infectivity paralleling a rise in agglutination titre would mean that filaments and spheres would show about the same ratio of I.D. 50 doses to an agglutinating dose. So far as can be seen from our experiments filtrates of A/Persian Gulf/2/52 virus show a ratio of I.D. 50 doses to an agglutinating dose which is about equal to that of preparations of this strain containing abundant filaments. If the spheres are in fact normally derived from breakdown of the filaments, our results would suggest that a filament with a probability of about 1 in 10 of initiating infection in the allantoic cavity is naturally broken down into a number of spherical forms each with a probability of about 1 in 10. Hence a virus filament has a greater efficiency than a sphere in agglutinating red cells but this is unaccompanied by any increased efficiency in initiating infection.

In our experiments with ultrasonic vibrations of a filamentous strain the rise in agglutinin titre was unaccompanied by any change in infectivity. We might suppose that a rise in infectivity was masked by a corresponding drop due to virus inactivation, but there is no support for this suggestion from similar experiments with a non-filamentous strain in which no virus inactivation occurred. We are left with the belief that natural breakdown of filaments 
Journal of General Microbiology, Vol. 11, No. 2
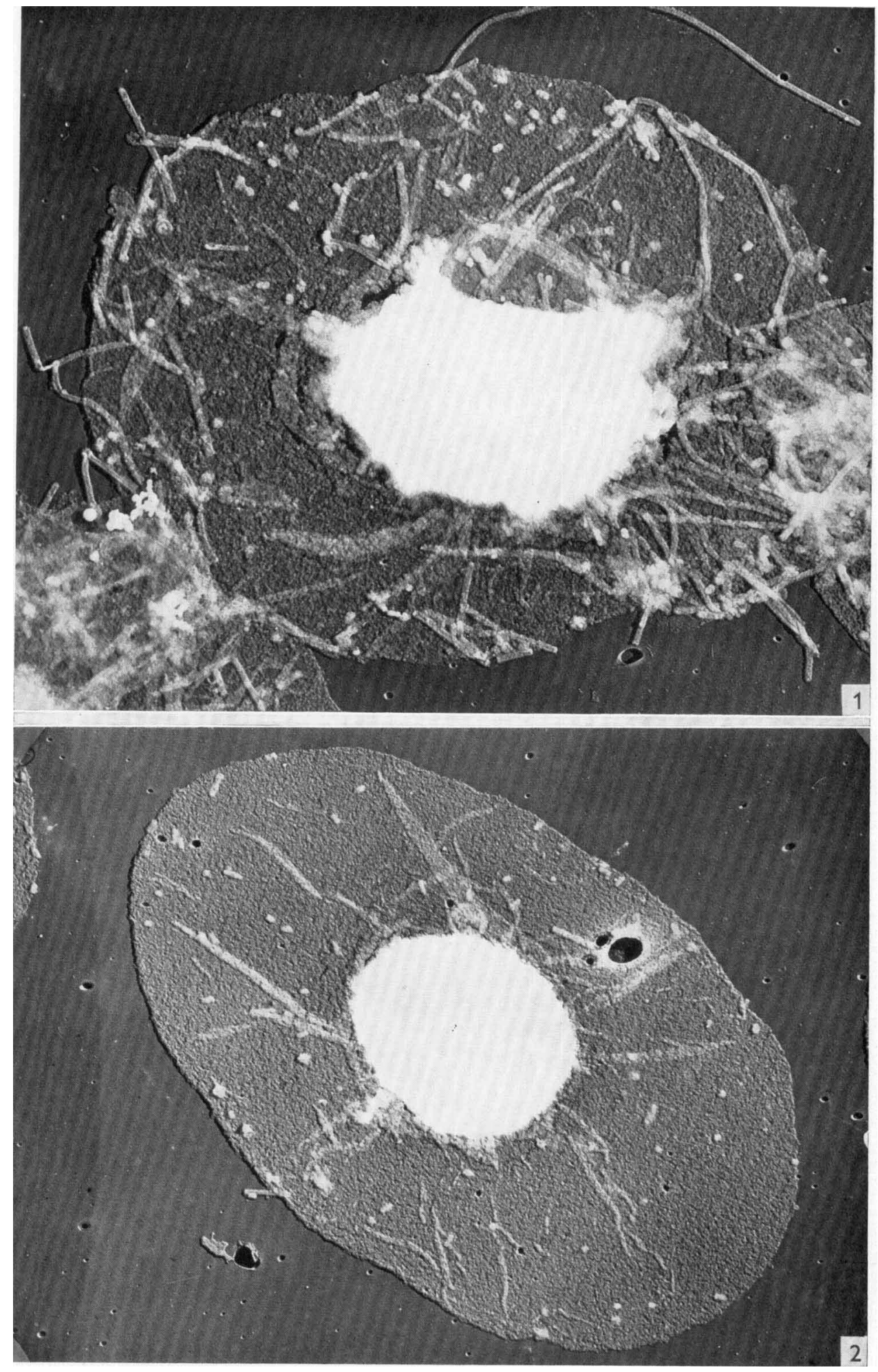

H. B. Donald \& A. Isaacs-Influenza virus filaments. Plate 1 
Journal of General Microbiology, Vol. 11, No. 2
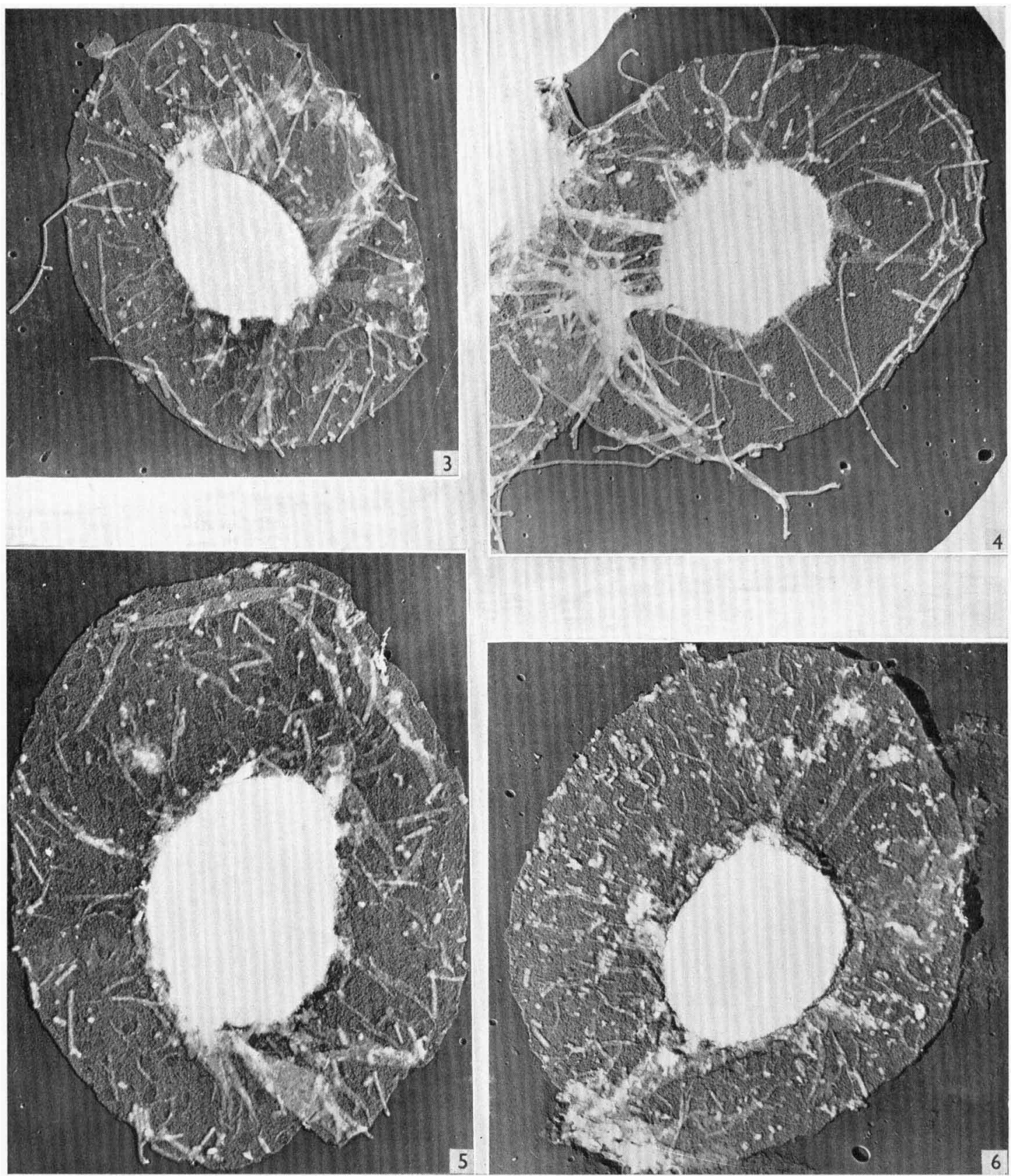

H. B. Donald \& A. Isaacs-Influenza virus milaments. Plate 2 
into spheres is not a simple mechanical process which can be imitated by treatment with ultrasonic vibrations.

We should like to thank Mrs I. M. Honey and Messrs E. Owen and O. Green for their very valuable technical assistance.

\section{REFERENCES}

Chu, C. M., Dawson, I. M. \& Elford, W. J. (1949). Filamentous forms associated with newly isolated influenza virus. Lancet, i, 602.

Donald, H. B. \& IsaAcs, A. (1954). Counts of influenza virus particles. J. gen. Microbiol. 10, 457.

HoYse, L. (1950). The multiplication of influenza viruses in the fertile egg. J. Hyg., Camb. 48, 277.

Mosley, V. M. \& WyCkoff, R. W. G. (1946). Electron micrography of the virus of influenza. Nature, Lond. 157, 263.

Murphy, J. S., Karzon, D. T. \& BANG, F. B. (1950). Studies of influenza A (P.R. 8) infected tissue cultures by electron microscopy. Proc. Soc. exp. Biol., N.Y. 73, 596.

Wyckoff, R. W. G. (1951). Electron microscopy of chick embryo membrane infected with P.R. 8 influenza. Nature, Lond. 168, 651.

\section{EXPLANATION OF PLATES}

Plate 1

Fig. 1. Laked fowl erythrocyte with adsorbed A/Persian Gulf/2/52 virus. Shadow cast with gold-manganin. $\times 12,000$.

Fig. 2. A/Persian Gulf/2/52 virus after filtration through gradocol membrane A.P.D. $0.7 \mu . \quad \times 10,000$.

\section{Plate 2}

Fig. 3. A/Persian Gulf/2/52 virus supernatant after centrifugation at $1500 \mathrm{~g}$ for $15 \mathrm{~min}$. $\times \mathbf{7 5 0 0}$.

Fig. 4. A/Persian Gulf/2/52 virus deposit after centrifugation at $1500 \mathrm{~g}$ for $15 \mathrm{~min} . \times 7500$.

Fig. 5. A/Persian Gulf/2/52 virus after treatment with 6 kc. sonic vibrations for $3 \mathrm{~min}$. $\times 9000$.

Fig. 6. A/Persian Gulf/2/52 virus after treatment with 350 kc. ultrasonic vibrations for $3 \mathrm{~min} . \times 9000$. 


\section{CORRIGENDUM}

In Donald, H. B. \& Isaacs, A. (1954). J. gen. Microbiol. 10, 457-464. On page 463 footnote to read:

* Luria (1953) states: "The numerical relation between successful particles and actual virus particles cannot be decided by titration or by any other statistical tests, but only by actual counts or determinations of particle numbers." 